\title{
Patterns in the photosynthetic metabolism of Mediterranean macrophytes
}

\author{
Susana Enríquez ${ }^{1}$, Carlos M. Duarte ${ }^{2}$, Kaj Sand-Jensen ${ }^{1}$ \\ ${ }^{1}$ Freshwater Biological Laboratory, University of Copenhagen, 51 Helsingersgade, DK-3400 Hillerød, Denmark \\ ${ }^{2}$ Centro de Estudios Avanzados de Blanes, CSIC, Camí de Santa Bárbara s/n, E-17300 Blanes, Girona, Spain
}

\begin{abstract}
Here we examine the relationship between the photosynthetic performance of a wide range of Mediterranean marine macrophyte species $(5$ angiosperms and 18 macroalgae of widely different size and growth form), and several descriptors of the photosynthetic tissue such as thickness, chlorophyll a ( $\mathrm{chl} \mathrm{a}$ ) and nutrient (C, N, P) content. The photosynthetic performance of the plants is described by their photosynthesis-irradiance curves, either as continuous functions, or as the individual parameters defining the curves. Our results demonstrate a strong relationship between the photosynthetic efficiency $(\alpha)$ measured at low light and the photosynthetic rate at saturating light $\left(P_{\max }\right)$, and show $\alpha$ to be closely related to differences in tissue thickness and chl a concentration among the marine macrophytes examined. The interaction between thickness and chl a concentration in the regulation of $\alpha$ is parallel to their interaction in the regulation of light absorption properties. Tissue thickness and pigment concentration not only explained variation in individual photosynthetic parameters $\left(P_{\max }\right.$ and $\alpha$ ), but were also able to summarise differences in the response of photosynthesis to irradiance. The strong relationship between tissue thickness and photosynthetic performance lend support to the important adaptive role attributed to the thickness of marine macrophyte tissues in the past. This importance of thickness extends beyond the regulation of plant productivity to the resistance to grazing, mechanical damage and the longevity of the tissue. Considering previous demonstrations of the functional importance of thickness for phytoplankton and for land plants, we suggest the existence of a general relationship between tissue thickness and the photosynthetic performance of photosynthetic organisms.
\end{abstract}

KEY WORDS: Marine macrophytes · Photosynthetic rates - Thickness · Chlorophyll a Nitrogen $\cdot$ Phosphorus Allometric scaling

\section{INTRODUCTION}

Realization of the large contribution of marine macrophytes to the production of the coastal ocean (Smith 1981, Charpy-Roubaud \& Sournia 1990) has increased the interest in identifying the factors regulating their productivity. Examination of the relationship between resource availability, the physical factors that modulate their acquisition (e.g. turbulence), and the photosynthetic performance of marine macrophytes has revealed considerable variation among macrophyte species (e.g. Nielsen \& Sand-Jensen 1989, 1990, Madsen et al. 1993), suggesting the existence of intrinsic differences in the photosynthetic performance of marine macrophytes. This finding has fostered comparative studies to identify the intrinsic characteristics of marine macrophytes that constrain their photosyn- thetic properties, and that should reflect the different trade-offs which affect their success in nature.

Early comparative work on marine macrophytes provided evidence that species with different types of thalli have different photosynthetic performances (e.g. Littler 1980). Thin sheet-like forms are the most productive, and thick sheet-like forms and saxicolous prostrate forms are the least productive. This 'Functional-Form' hypothesis (Littler 1980) stimulated research on the functional implications of thallus form. It has been shown that photosynthetic rates decrease with increasing thallus thickness, both at light limitation (e.g. King \& Schramm 1976) and light saturation (e.g. Lüning \& Dring 1985, Nielsen \& Sand-Jensen 1990). Parallel to these findings, differences in tissue thickness and chlorophyll a ( $\mathrm{chl}$ a) content have been shown to account for most of the differences in light 
absorption properties across a broad spectrum of marine macrophytes (Ramus 1978, Frost-Christensen \& Sand-Jensen 1992, Enríquez et al. 1994), in agreement with predictions from optical theory (Morel \& Bricaud 1981, Kirk 1983) and empirical results for other plant types (Agustí 1991, Agustí et al. 1994, Enríquez et al. 1994). These results provide a mechanistic basis for the strong constraints which tissue thickness appears to impose on the photosynthetic performance of marine macrophytes, and suggest that it should be possible to describe the photosynthetic repertoire observed in marine macrophytes as a continuous function of thickness of the tissues and their chl a concentration. Use of continuous scaling variables (e.g. thickness of the photosynthetic tissue) to describe plant functional properties has several advantages to the use of categorical variables [i.e. form groups advocated by Littler (1980) for macroalgae, and terrestrial growth form and strategy concepts developed by Raunkiaer (1934) and Grime (1974)], because continuous form variables and functional properties allow quantitative predictions and tests.

Here we test the hypothesis that differences in the photosynthetic metabolism of marine macrophyte tissues are scaled to their thickness and pigmentation by examining the relationship between the thickness and chI a content and the photosynthetic performance of a wide range of Mediterranean marine macrophytes, including 5 angiosperm species and 18 macroalgae species of widely different size and growth form. Chl a content is used here to represent pigmentation because it is the unique universal pigment present in all macrophyte groups. In addition, it is the only plant pigment involved in the reaction center of photosynthesis (e.g. Staehelin 1986). Moreover, chl a and tissue thickness have been shown to account for a large fraction of the variance in macrophyte light absorption properties in this broad assemblage of marine marophytes (Enríquez et al. 1994). We will also examine the relationship between tissue nutrient content and photo-

Table 1. List of species, means of properties measured, and numbers of populations $\left(N_{0}\right)$ for each species of NW Mediterranean macrophyte examined. Units: $P_{\max }$ and $R\left(\mathrm{mg} \mathrm{O}_{2} \mathrm{~g}^{-1}\right.$ dry wt h$\left.{ }^{-1}\right) ; \alpha\left[\mathrm{mg} \mathrm{O}_{2} \mathrm{~g}^{-1}\right.$ dry $\left.w \mathrm{~h} \mathrm{~h}^{-1}\left(\mu \mathrm{mol} \mathrm{m}^{-2} \mathrm{~s}^{-1}\right)^{-1}\right] ; I_{c}\left(\mu \mathrm{mol} \mathrm{m}^{-2} \mathrm{~s}^{-1}\right) ;$ thickness $(\mathrm{mm})$; chl $a, \mathrm{C}, \mathrm{N}$ and $\mathrm{P}(\%$ dry wt)

\begin{tabular}{|c|c|c|c|c|c|c|c|c|c|c|}
\hline Species & $P_{\max }$ & $\alpha$ & $R$ & $I_{c}$ & Thickness & Chl a & $\mathrm{C}$ & $\mathrm{N}$ & $P$ & $N_{0}$ \\
\hline \multicolumn{11}{|l|}{ Angiosperms } \\
\hline Cymodocea nodosa (Ucria) Ascherson & 8.39 & 0.0462 & 2.36 & 61 & 0.220 & 0.335 & 37.24 & 2.44 & 0.263 & 9 \\
\hline Posidonia oceanica (L.) Delile & 6.99 & 0.0458 & 0.97 & 21 & 0.201 & 0.466 & 38.12 & 1.76 & 0.136 & 16 \\
\hline Ruppia maritima L. & 15.94 & 0.0615 & 1.43 & 23 & 0.320 & 0.141 & 36.57 & 2.37 & - & 1 \\
\hline Zostera maritima L. & 6.85 & 0.0460 & 1.70 & 40 & 0.175 & 0.492 & 34.70 & 1.91 & 0.293 & 9 \\
\hline Zostera noltii Hornem & 12.12 & 0.0456 & 2.72 & 56 & 0.179 & 0.411 & 34.84 & 1.94 & 0.209 & 14 \\
\hline \multicolumn{11}{|l|}{ Macroalgae } \\
\hline Acetabularia sp. & 1.53 & 0.0073 & 0.58 & 79 & 2 & 0.097 & 22.16 & 0.56 & 0.030 & 3 \\
\hline Caulerpa prolifera (Forskal) Lamour. & 6.98 & 0.0466 & 1.21 & 28 & 0.208 & 0.445 & 35.60 & 3.17 & 0.154 & 4 \\
\hline Codium bursa J. Agardh & 0.37 & 0.0070 & 1.43 & 140 & 8.5 & 0.168 & 16.04 & 4.17 & 0.295 & 2 \\
\hline C. effusum (Rafinesque) Delle Chiaje & 0.26 & 0.0036 & 0.34 & 95 & 4 & 0.037 & 15.84 & 0.92 & 0.042 & 1 \\
\hline C. vermilaria (Olive) Delle Chiaje & 2.40 & 0.0095 & 0.24 & 25 & 3 & 0.195 & 24.69 & 2.20 & 0.130 & 1 \\
\hline Codium sp. & 1.93 & 0.0275 & 0.68 & 25 & 2.5 & 0.279 & 18.56 & 1.25 & 0.060 & 1 \\
\hline Enteromorpha compressa (L.) Greville & 26.85 & 0.0860 & 1.76 & 21 & 0.171 & 0.571 & 24.35 & 1.87 & 0.09 & 1 \\
\hline Halimeda tuna (Ellis et Solander) Lamour. & 2.27 & 0.0203 & 2.40 & 121 & 1.11 & 0.291 & 25.67 & 3.00 & 0.284 & 9 \\
\hline Udotea petiolata (Turra) Nizamudin & 5.24 & 0.0411 & 3.40 & 92 & 0.337 & 0.532 & 36.64 & 5.17 & 0.282 & 3 \\
\hline Ulva rigida C. Agardh & 26.43 & 0.0833 & 1.95 & 24 & 0.113 & 0.324 & 23.93 & 2.25 & 0.100 & 4 \\
\hline Cytoseira mediterranea Sauvageau & 4.15 & 0.0176 & 0.83 & 51 & 0.708 & 0.225 & 34.13 & 1.84 & 0.090 & 3 \\
\hline Dyctiota dichotoma (Huds.) Lamour & 11.98 & 0.0442 & 1.18 & 27 & 0.164 & 0.154 & 30.89 & 1.97 & 0.110 & 1 \\
\hline Padina pavonica (L.) Lamour. & 3.08 & 0.0131 & 0.61 & 122 & 0.841 & 0.117 & 21.73 & 1.30 & 0.080 & 3 \\
\hline Dasycladus sp. & 7.38 & 0.0239 & 1.09 & 46 & 0.721 & 0.226 & 23.58 & 2.31 & 0.07 & 1 \\
\hline Hypnea cervicornis J. Agardh & 13.43 & 0.0423 & 1.96 & 39 & 0.666 & 0.066 & 22.27 & 1.92 & 0.110 & 1 \\
\hline Jania sp. & 2.53 & 0.0188 & 0.70 & 37 & 0.268 & 0.075 & 18.02 & 1.21 & 0.07 & 1 \\
\hline Porphyra sp. & 38.07 & 0.1663 & 1.99 & 13 & 0.041 & 0.297 & 30.73 & 2.54 & - & 1 \\
\hline Rissoella verruculosa (Bertoloni) J. Agardh & 3.89 & 0.0335 & 1.21 & 36 & 0.414 & 0.121 & 33.45 & 2.79 & 0.130 & 3 \\
\hline Mean & 8.24 & 0.041 & 1.80 & 57 & 0.664 & 0.348 & 31.9 & 2.33 & 0.191 & - \\
\hline $\mathrm{SE}$ & 0.76 & 0.003 & 0.15 & 6 & 0.15 & 0.018 & 0.75 & 0.12 & 0.012 & - \\
\hline Range & 0.11 & 0.002 & 0.091 & 8 & 0.041 & 0.037 & 13.28 & 0.36 & 0.02 & - \\
\hline $\operatorname{Max}$ & 38.07 & 0.166 & 6.45 & 301 & 9 & 0.938 & 40.9 & 7.07 & 0.57 & - \\
\hline No. of determinations & 90 & 90 & 90 & 90 & 88 & 90 & 84 & 84 & 81 & - \\
\hline
\end{tabular}


synthetic performance, because the nitrogen content of plant tissues has also been shown to help account for differences in photosynthetic rate among plants (e.g. Field \& Mooney 1986, Chapin et al. 1987, Evans 1989). The photosynthetic performance of the plants was described by their photosynthesis-irradiance $(P-I)$ curves, either as continuous functions describing the curve, or as the individual parameters defining the curves [maximum photosynthetic rate, $P_{\max }$ photosynthetic efficiency, $\alpha$ (i.e. the initial linear slope of $P$ vs $I$ ); light compensation point, $I_{c}$; and dark respiration rate, $R]$.

\section{MATERIAL AND METHODS}

We examined $90 P$ - I curves derived from 5 species of angiosperms and 18 species of macroalgae growing on the Spanish coast of the NW Mediterranean (Table 1). The units of the analysis are not the different species sampled, but the different populations of macrophytes studied, because the sampling was designed to encompass the maximum morphological and pigmentary variability of the macrophytes present in the region. The variability, therefore, comprises both differences among species and the considerable plasticity within some species. The specimens were collected by divers between 0.5 and $15 \mathrm{~m}$ depth from 19 locations along the Spanish Mediterranean coast. All locations have clear waters and most samples were retrieved from water depths receiving $>10 \%$ of the surface irradiance. The majority of the samples were collected between May and September 1991 and 1992. Samples of the 4 seagrass species that coexist in a shallow cove (Cala Junquet-Girona), however, were sampled year round. We considered them in our analysis to include seasonal variability as well.

The $P$-I curves were measured on epiphyte-free photosynthetic tissues with a fully developed pigmentary composition. For the seagrasses we used leaf number 2 for Posidonia oceanica and Zostera marina and leaf numbers 1 or 2 for Zostera noltii and Cymodocea nodosa. The photosynthetic tissue was incubated in clear glass bottles exposed to different light intensities, and the photosynthetic activity was measured through changes in dissolved oxygen concentration, following the recommendations of Littler (1979), Littler \& Arnold (1982) and Kemp et al. (1990), particularly in regard to incubation time, stirring of the water, and sample size (fresh weight relative to bottle volume). The plant tissue sections were fitted into $280 \mathrm{ml}$ Winkler bottles, filled with filtered $(0.45 \mu \mathrm{m})$ air-saturated seawater, using a siphon to prevent bubble formation and reduce variance in the oxygen concentration among replicates, and incubated at $20^{\circ} \mathrm{C}$, close to the average sea- water temperature between May and September, in a MK X Incubator Shaker (LH Fermentation). Stirring was provided by continuous orbital shaking or magnetic stirring bars. Incubation time for each light intensity measurement ranged between $45 \mathrm{~min}$ and $4 \mathrm{~h}$, and was scaled to the rate of oxygen change to ensure accurate estimates of oxygen production in the light and consumption in the dark while keeping oxygen concentration within $\pm 40 \%$ of the equilibrium level at air saturation. The decline of dissolved inorganic carbon during incubation in the light was small $(<0.08 \mathrm{mM})$ relative to the ambient level at $2.20 \mathrm{mM}$, assuming $1.25 \mathrm{~mol} \mathrm{O}_{2}$ is produced for every mol C consumed. The changes in dissolved oxygen were measured using an oxygen electrode and meter (Orbisphere, 2607 model, sensor 2112 with a built-in stirrer). We used 3 reference (i.e. without macrophytes) bottles incubated at the same light intensities and during the same time period, and 3 replicate treatment bottles per experiment. Illumination was provided by cool-white fluorescent tubes placed above the bottles, and the photon fluence rate was measured with a spherical LICOR sensor connected to a LI-COR data-logger.

The $P$ - $I$ curves were derived from consecutive measurements on the same sample in the dark and at increasing photon flux density $(15,35,70,150,300$, 425, 500 and $750 \mu \mathrm{mol} \mathrm{m} \mathrm{m}^{-2} \mathrm{~s}^{-1}$ ) to reduce betweensample variability. The $P$-I curves were used to calculate the following photosynthesis parameters: the photosynthetic efficiency ( $\alpha$; cf. Kirk 1983) estimated from the initial slope calculated by linear regression (e.g. Ledermann \& Tett 1981); dark respiration rate $(R)$, which represents the intercept of the regression equation with the ordinate axis, and the light compensation point $\left(I_{\mathrm{c}}\right)$ calculated as the intercept of the regression equation with the abscissa, which represents the irradiance at which photosynthesis and respiration are balanced. The maximum photosynthetic rate $\left(P_{\max }\right)$ was usually reached at light intensities below the highest light intensity applied $\left(750 \mu \mathrm{mol} \mathrm{m} \mathrm{m}^{-2} \mathrm{~s}^{-1}\right)$, but in a few experiments photosynthesis was not fully saturated at this irradiance, and $P_{\max }$ in these instances is a minimum estimate; $P_{\max }$ represents the maximum photosynthetic rate attainable at, or close to, light saturation in natural seawater at air saturation and $\mathrm{pH}$ 8.2. We do not exclude that photosynthesis was not fully saturated by the supply of inorganic carbon in the natural seawater.

Following completion of $P$ - $I$ curves we measured tissue thickness, specific area (surface area/dry weight) and contents of chl $a$ and nutrients $(C, N$, and $P$ ) of each sample of photosynthetic tissue. We measured the thickness of the photosynthetic structure either directly for thick (>2 mm) tissues or from measurements of the specific area, assuming a density of 1 of 
the fresh tissues. Chl a was measured spectrophotometrically following pigment extraction with $80 \%$ acetone in a homogenized suspension (Dennison 1990). C and N contents were determined in duplicate subsamples using a Carbo-Erla CHN analyzer, and P content was measured colorimetrically following tissue digestion in boiling concentrated acid (Koroleff 1983).

The relationships among variables were described using least-squares regression analyses of log-transformed data. Logarithmic transformation was found to be necessary to avoid heteroscedasticity in the regression analyses (Draper \& Smith 1966). The simultaneous influence of several variables was tested using multiple least squares regression analyses, and the statistical relationships between these factors and the dependent variable were further examined using partial correlation analysis (e.g. Sokal \& Rohlf 1979). The influence of tissue thickness and chl a content on the photosynthetic response to increasing photon flux density was examined by testing, using analysis of covariance, their effect on the parameters of the linear form of the Burke \& Lineweaver model (1935) (cited in Ledermann \& Tett 1981),

$$
\frac{1}{P_{\text {gross }}}=\frac{1}{P_{\max }}+\left(\frac{1}{\alpha}\right)\left(\frac{1}{I}\right)
$$

which describes the relationship between the inverse of gross photosynthesis $\left(1 / P_{\text {gross }}\right.$, where $\left.P_{\text {gross }}=P+R\right)$ and that of the irradiance (1/I) using 2 parameters, corresponding to the inverse of $P_{\max }$ and $\alpha$, respectively. This equation fitted well to our $P$ - $I$ curves (average correlation coefficient for $10 P$ - $I$ curves: $0.96, \mathrm{p}<0.001$ ).

\section{RESULTS AND DISCUSSION}

The marine macrophytes examined showed a broad variation in the variables measured (Table 1). The metabolic parameters and thallus thickness ranged over 2 to 3 orders of magnitude whereas tissue composition was much less variable. The photosynthetic rates showed great variablility when normalised to chl $a_{\text {, }}$ surface area, and, in particular, dry weight (Fig. 1). The physiological descriptors were all significantly intercorrelated (Table 2). $P_{\max }$ and $\alpha$ were strongly positively related (Fig. 2), such that macrophytes with high photosynthetic efficiency at low light also tended to exhibit high photosynthetic rates at light saturation. The relationship between $P_{\max }$ and $\alpha$ was strong when photosynthesis was referred to dry weight, and to chl a (Eqs. 1 \& 2 respectively in Table 2).

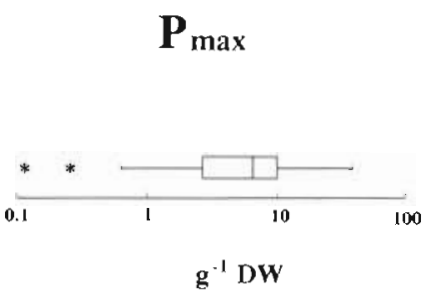

$\alpha$
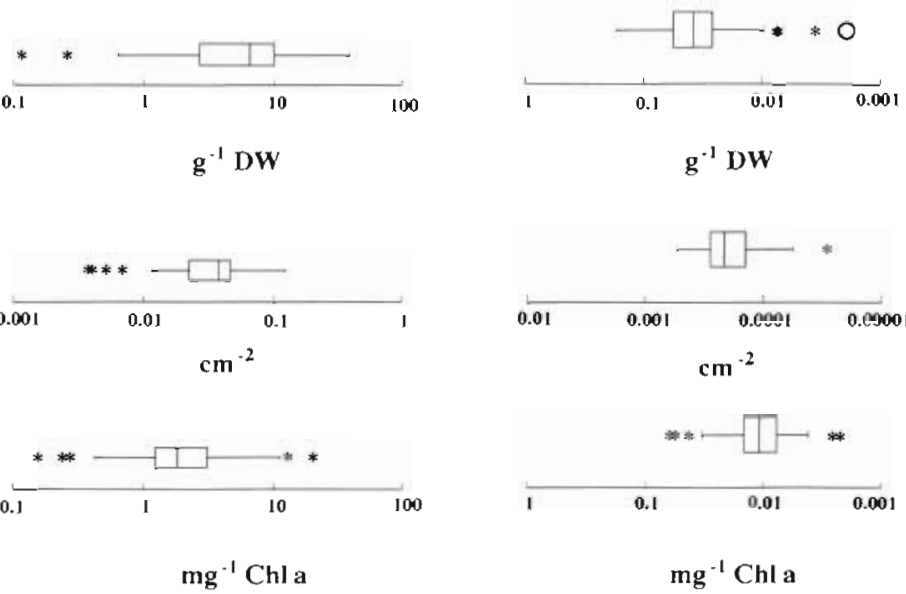

Fig. 1. Box plots showing the distribution of photosynthetic rates $\left[P_{\max }=m g \mathrm{O}_{2} \mathrm{~h}^{-1} ; \alpha=\mathrm{mg} \mathrm{O} \mathrm{O}_{2} \mathrm{~h}^{-1}\left(\mu \mathrm{mol} \mathrm{m} \mathrm{m}^{-2} \mathrm{~s}^{-1}\right)^{-1}\right]$ per unit of dry weight, surface area and chl a units. Boxes encompass the 25 and $75 \%$ quartiles, the central line represents the median, bars extend to the $95 \%$ confidence limits; *observations extending beyond the $95 \%$ confidence limits (O) observations beyond the $99 \%$ confidence limits
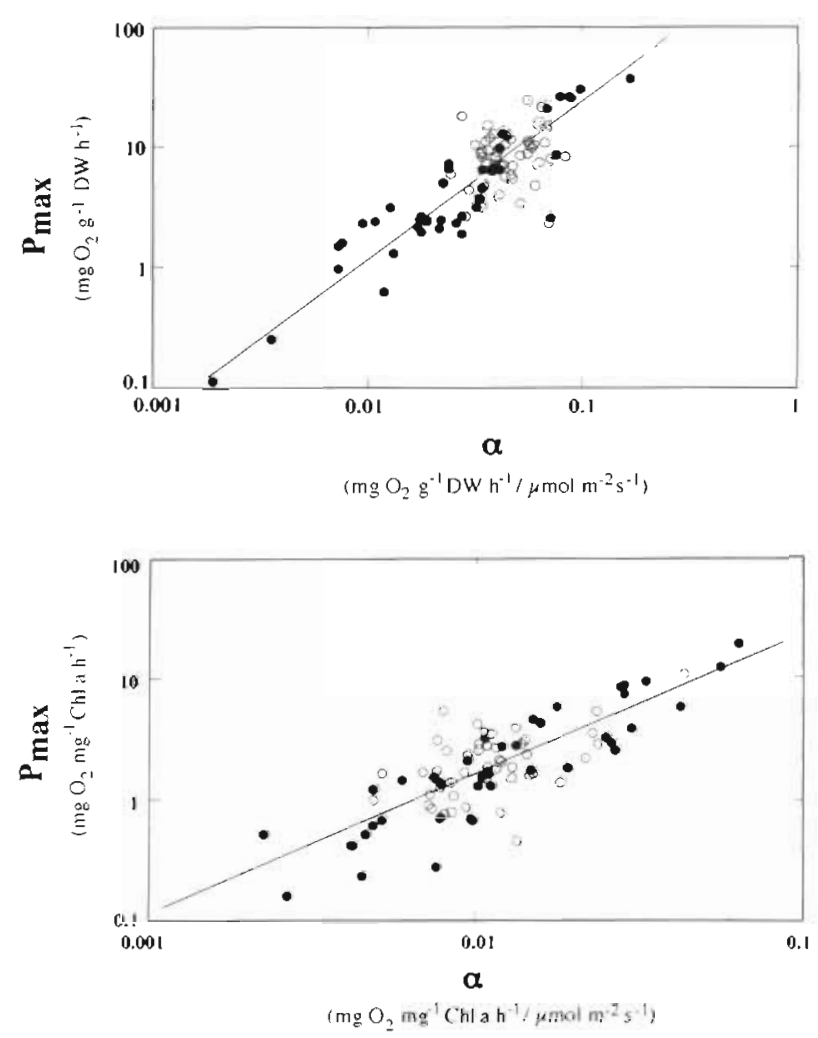

Fig. 2. Relationship between maximum photosynthetic rate $\left(P_{\text {max }}\right)$ and photosynthetic efficiency $(\alpha)$ of NW Mediterranean macrophytes, in terms of dry weight and chl a units. (O) Angiosperms; $(\bullet)$ macroalgae 
Table 2. Pearson correlation coefficients between the variables measured in the NW Mediterranean macrophytes. dw: photosynthetic rates given in terms of dry weight $\left[P_{\max }, \mathrm{mg} \mathrm{O}_{2} \mathrm{~g}^{-1}\right.$ dry wt h${ }^{-1} ; \alpha_{2} \mathrm{mg} \mathrm{O}_{2} \mathrm{~g}^{-1}$ dry wt h $\left.\mathrm{h}^{-1}\left(\mu \mathrm{mol} \mathrm{m}^{-2} \mathrm{~s}^{-1}\right)^{-1}\right]$; chl: photosynthetic rates given in terms of chl a $\left[P_{\max }, \mathrm{mg} \mathrm{O}_{2} \mathrm{mg}^{-1} \mathrm{chl} \mathrm{a} \mathrm{h}^{-1} ; \alpha, \mathrm{mg} \mathrm{O}_{2}\right.$ $\mathrm{mg}^{-1} \mathrm{chl} \mathrm{a} \mathrm{h}^{-1}\left(\mu \mathrm{mol} \mathrm{m} \mathrm{m}^{-2} \mathrm{~s}^{-1}\right)^{-1}$. Other units: thickness, mmi chl a, \% dry wt

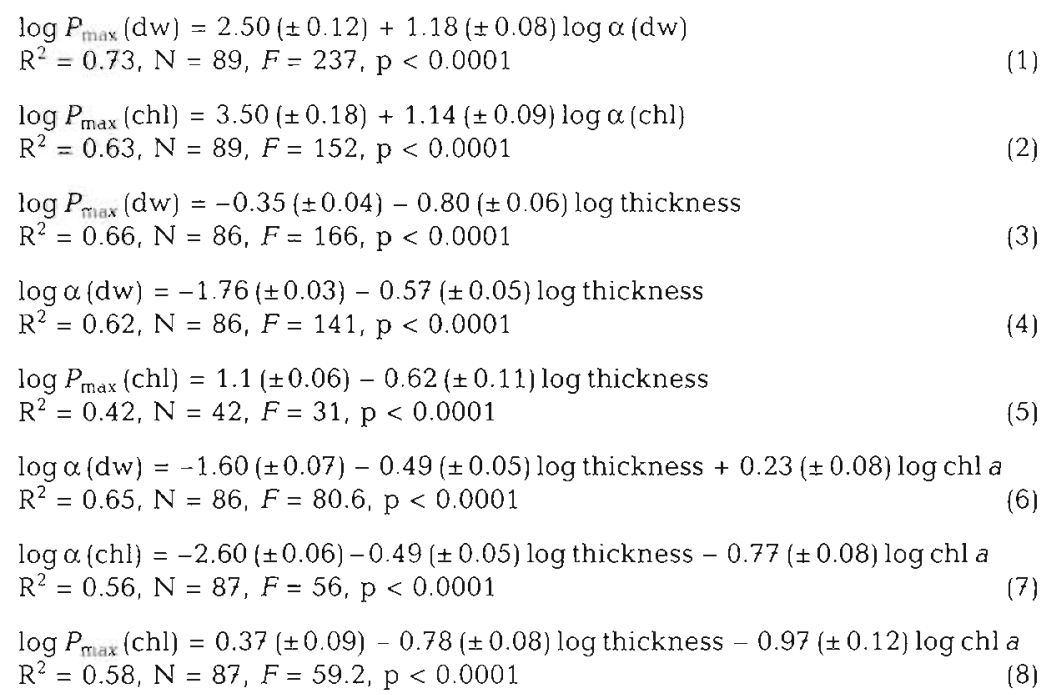

Table 3. Pearson correlation coefficients between the variables measured in the NW Mediterranean macrophytes. Units as in Table $1{ }^{\prime \prime} p<0.001 ; \cdot p<0.05 ;{ }^{n s} p>0.05$

\begin{tabular}{|c|c|c|c|c|c|c|c|c|}
\hline & $P_{\max }$ & $R$ & $I_{c}$ & $\alpha$ & Thickness & Chl a & $N$ & $\mathrm{P}$ \\
\hline$R$ & $0.39^{\circ}$ & & & & & & & \\
\hline$I_{\mathrm{c}}$ & $-0.42 \cdots$ & $0.55^{\circ}$ & & & & & & \\
\hline$\alpha$ & $0.86^{\circ}$ & $0.47^{\circ}$ & $-0.46^{\cdots}$ & & & & & \\
\hline Thickness & $-0.81^{\cdots}$ & $-0.25^{\circ}$ & $0.47^{\cdots}$ & $-0.79^{*}$ & & & & \\
\hline Chl a & $0.47^{\cdots}$ & $0.21^{\mathrm{ns}}$ & $-0.33^{\circ}$ & $0.58 \cdots$ & $\cdot-0.53^{\cdots}$ & & & \\
\hline $\mathrm{N}$ & $0.16^{\mathrm{ns}}$ & $0.47^{\cdots}$ & $0.27^{\star}$ & $0.24^{*}$ & $-0.04^{\mathrm{ns}}$ & $0.34^{\circ}$ & & \\
\hline $\mathrm{P}$ & $0.16^{\mathrm{ns}}$ & $0.61^{*}$ & $0.42 \cdots$ & $0.26^{*}$ & $-0.13^{\mathrm{ns}}$ & $0.35^{\circ}$ & $0.71^{\circ}$ & \\
\hline C & $0.48^{\circ}$ & $0.24^{\circ}$ & $-0.26^{\circ}$ & $0.56^{\cdots}$ & $=-0.63 \cdots$ & $0.63^{\cdots}$ & $0.48^{\circ}$ & $0.45^{\circ}$ \\
\hline
\end{tabular}

remain unchanged (Geider \& Osborne 1992). Our observations agree also with a stoichiometrical coupling between resources directed at controlling $\alpha$ (i.e. light harvesting capacity) and $P_{\max }$ (i.e. carbon fixation capacity) as has been previously observed in comparisons within (SandJensen 1988, Bijl et al. 1989) and among aquatic macrophyte species (Sand-Jensen \& Madsen 1991).

Examination of the relationships between photosynthesis and respiration and the thickness, pigment and nutrient ( $C, N, P$ ) content of the tissues helped account for the large functional variation found. Carbon content showed stronger relationships with the photosynthetic rates than with dark respiration rate. Nitrogen and phosphorus concentrations showed little or no relationship to the photosynthetic rates (Table 3), even though the data set included specimens likely to be nutrient limited (i.e. $67 \%$ of the samples had $<0.2 \%$ P of dry weight and $40 \%$ had $<1.8 \% \mathrm{~N}$ of dry weight; $\mathrm{cf}$. Duarte 1992). Light compensation points tended to increase with increasing thickness and phosphorus concentration, and together the 2 variables accounted for $45 \%$ of the variation in $I_{c}$. An increase in compensation irradiance with increasing thickness had been predicted from the decline in light absorption per unit biomass with increasing thick-

These equations indicate that $P_{\max }$ increases faster than $\alpha$, exhibiting a slope slightly greater than 1 . Hence, NW Mediterranean macrophytes that have low photosynthetic rates at low light also have low photosynthetic rates at high light. Conversely, those macrophytes that display a high photosynthetic rate at low light do so also at high light. The relationship between the 2 photosynthetic parameters normalised to surface area was also positive but weaker $\left(R^{2}=0.34, p<0.001\right)$ than those described above, and it had a slope significantly less than $1(0.75 \pm 0.11$, $t$-test, $p<0.001)$, reflecting that $\alpha$ increases faster than $P_{\max }$ when referred to surface area. Our findings agree with the oftenobserved covariation between $\alpha$ and $P_{\max }$ among phytoplankton species (Harding et al. 1987), which has been explained in terms of changes in the number of active photosynthetic units, when all others factors ness of the macrophyte tissues (Agustí et al. 1994, Enríquez et al. 1994), and this prediction is supported by our analysis. The relationship of $I_{c}$ to phosphorus concentration may reflect the increase in dark respiration rates with increasing $P$ concentration (Table 3 ). The fact that the metabolic parameters are correlated to $P$ and not to $N$ concentrations suggests a greater importance of $\mathrm{P}$, consistent with the greater proportion of these Mediterranean macrophytes with $\mathrm{P}$ concentrations below critical levels, compared to that of $\mathrm{N}$.

Maximum photosynthetic rates and photosynthetic efficiency referred to dry weight were strongly, negatively correlated to the thickness of the photosynthetic tissues (Fig. 3, Table 3; Eqs. $3 \& 4$ in Table 2). Thickness was unable to explain a large fraction of the variability displayed by the photosynthetic rates $\left(P_{\max }, \alpha\right)$ normalised to chl $a$ and surface area for all the macro- 

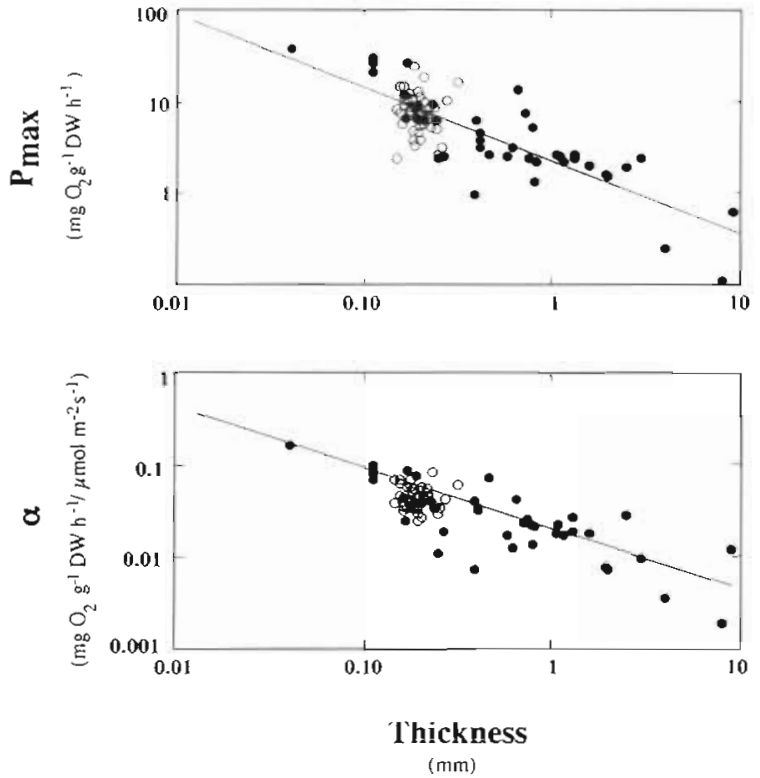

Fig. 3. Relationship between maximum photosynthetic rate $\left(P_{\text {max }}\right)$, photosynthetic efficiency $(\alpha)$, and the thickness of NW Mediterranean marrophyte tissues. Symbols as in Fig. 2

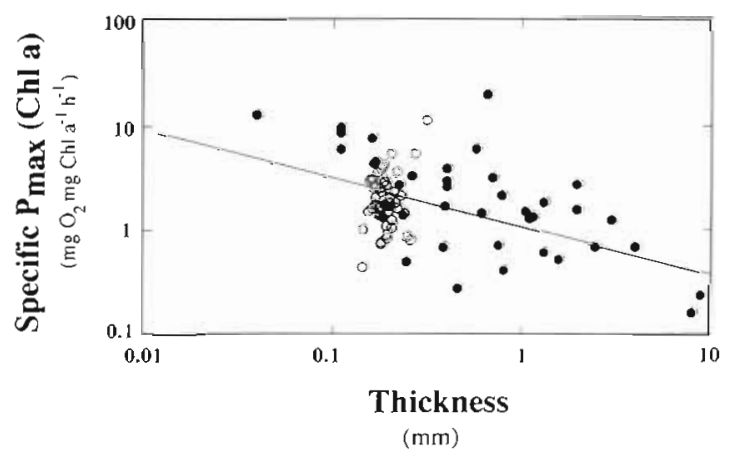

Fig. 4. Relationship between maximum photosynthetic rate $\left(P_{\text {rax }}\right)$ in terms of chl a and the thickness of NW Mediterranean macrophyte tissues. Symbols as in Fig. 2

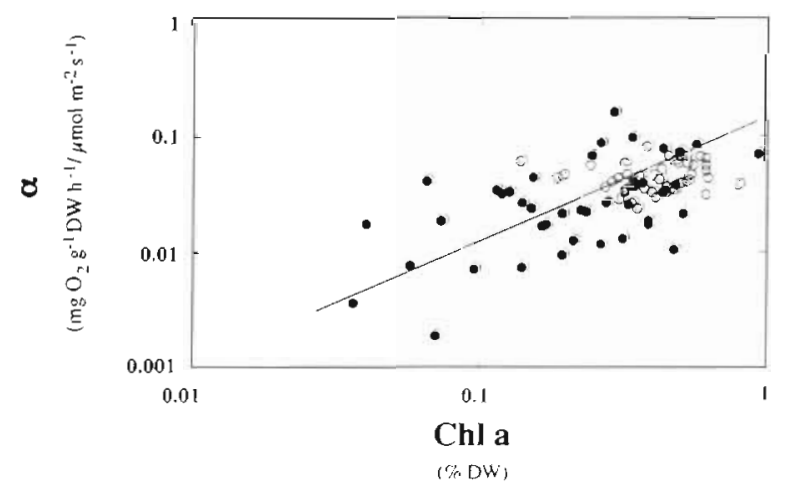

Fig. 5. Relationship between photosynthetic efficiency $(\alpha)$ and chl a concentration of the photosynthetic tissues of NW Mediterranean macrophytes. Symbols as in Fig. 2 phytes. Though weak, both Pearson correlation coefficients between $P_{\text {max }}$ and thickness were, however, significant $\left(\mathrm{r}_{\mathrm{chl} \mathrm{a}}=-0.49, \mathrm{r}_{\mathrm{cm}^{2}}=-0.35, \mathrm{p}<0.001\right)$, as was the correlation between thickness and $\alpha$ normalised to chl a $\left(\mathrm{r}_{\mathrm{chl} a}=-0.35, \mathrm{p}<0.001\right)$. Considering the macroalgal species only, thickness could account for $42 \%$ of the variability of maximum photosynthesis based on chl a (Fig. 4; Eq. 5 in Table 2). This relationship was not significant for the seagrasses alone. The slopes of the equations between the photosynthetic rates and thickness (Eqs. $3 \& 4$ ), indicate that $P_{\max }$ decreases faster with increasing thickness than $\alpha$ does (Figs. $3 \& 4$ ). The strong relationship between $\alpha, P_{\max }$ and thickness partially reflects indirect effects derived from the strong colinearity between $\alpha$ and $P_{\max }$, since the partial correlation coefficient between $\alpha$ and thickness, when accounting for $P_{\max }$, was -0.288 . The partial correlation between $P_{\text {max }}$ and thickness, when accounting for $\alpha$, was -0.374 . In both instances, however, the relationships of $\alpha$ and $P_{\max }$ to thickness remained negative and significant.

The low pigment concentration of marine macrophytes compared to those of land plants (Agustí et al. 1994) could also limit their photosynthetic rates. Indeed, the photosynthetic efficiency and maximum photosynthetic rate per unit of dry weight tended to increase with increasing tissue chl a concentration (Fig. 5, Table 3). This increase was, however, nonlinear, and regression analysis showed that $\alpha$ and $P_{\max }$ increased more slowly $\left(\alpha \approx \operatorname{chl} a^{0.63( \pm 0.1)} ; P_{\max } \approx\right.$ chl $a^{071( \pm 0.1)}$ ) than the chl a concentration did, such that macrophytes with high pigment content increased their photosynthetic efficiency and their maximum photosynthetic rate only marginally by increasing their chl a concentration further. This is, again, consistent with the asymptotic increase in light absorption with increasing chl a concentration (Agustí et al. 1994), which should lead to an asymptotic relationship with $\alpha_{1}$ which is closely related to the absorbance (e.g. Kirk 1983, Geider et al. 1986). Chl a concentration showed weak, but significant, Pearson correlations with photosynthetic rates referred to $\mathrm{chl} a\left(\mathrm{r}_{P_{\max }}=-0.318, \mathrm{r}_{\alpha}=\right.$ $-0.21, p>0.05$ ). No significant correlation was found between chl a concentration and the photosynthetic rates normalised to surface area.

For the photosynthetic rates expressed on a dry weight basis, simultaneous consideration of variation in thickness and chl a concentration (Eq. 6 in Table 2) did not increase very much the variation explained by considering thickness alone. The photosynthetic efficiency per unit of chl $a$, however, was clearly better explained by the multiple function including thickness and chl a. The 2 variables together accounted for 65 and $56 \%$ of the variation in the photosynthetic efficiency normalised to dry weight (Eq, 6 in Table 2) and 
chl a (Eq. 7 in Table 2), respectively, and for $58 \%$ of the variation in maximum photosynthetic rate based on chl a (Eq. 8 in Table 2).

Thickness and chl a showed significant coefficients ( $p<0.001$ ) in the 3 regression equations (Eqs. 6 to 8 in Table 2), and, although they covaried ( $\mathrm{r}=-0.53, \mathrm{p}<$ 0.001 ) and thickness accounted for an important fraction of the correlation between chl a concentration and $\alpha$ in Eq. 6 (63\%), the direct effect of the 2 independent variables on the photosynthetic rates still remained significant. Moreover, the partial correlation between photosynthetic rates per unit of chl $a$, and both plant traits showed strong associations $\left(\mathrm{r}_{\mathrm{p}} p_{\text {max }}\right.$-thickness $=-0.86$,

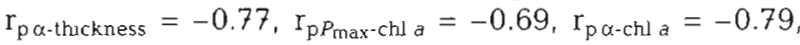
$p<0.001$ ), although the negative correlation between thickness and chl a veils this association and considerably decreases the Pearson correlations.

The photosynthetic rates per unit of chl a at low (Eq. 7) and at high light (Eq. 8) are negatively related to tissue thickness and chl a concentration. However, these plant traits have opposite effects on $\alpha$ expressed on a dry weight basis, since thin macrophytes have higher photosynthetic rates at low light for the same chl a content than those with thick tissues. The combined influence of thickness and chl a concentration (as they appear in the power function) was not able to account for the variability of the maximum photosynthetic rate per unit of dry weight (i.e. the coefficient for the chl a concentration was not significant, $p>0.1$ ). The simultaneous influence of thickness and chl a con-

Table 4. Equations and statistics of relationships between photosynthetic parameters and plant traits, for 116 species of marine macrophytes, collected from published reports and unpublished personal data. Units: $P_{\max }, \operatorname{mg~} \mathrm{O}_{2} \mathrm{~g}^{-1}$ dry wt $\mathrm{h}^{-1}$; $\alpha, \mathrm{mg} \mathrm{O}_{2} \mathrm{~g}^{-1}$ dry wt h${ }^{-1}\left(\mu \mathrm{mol} \mathrm{m}{ }^{-2} \mathrm{~s}^{-1}\right)^{-1}$; chl $\alpha_{1} \%$ dry wt

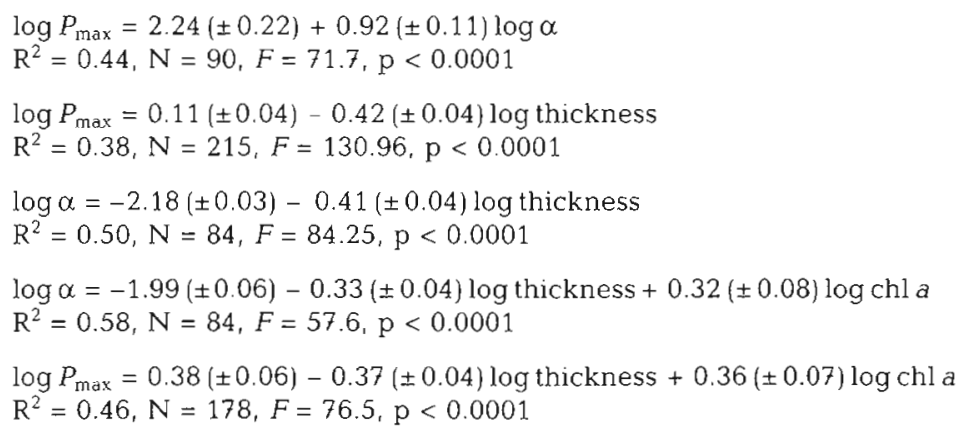

\section{Sources}

Macroalgae: Littler (1980), Littler \& Arnold (1982), Ramus (1983), Lipkin et al. (1986), Ramus \& Venable (1987), Kautsky (1988), Nielsen \& Sand-Jensen (1990), Ballesteros (1991), Enriquez et al. (1994), Sand-Jensen (unpubl.)

Seagrasses: Drew (1978), Dennison \& Alberte (1982), Josselyn \& Fonseca (1986), Dawes et al. (1987), Kautsky (1988), Tomasko \& Dawes (1989), FrostChristensen \& Sand-Jensen (1992), Durako (1993), Enríquez et al. (1994), Duarte \& Sand-Jensen (unpubl.), Sand-Jensen (unpubl.) centration on photosynthetic efficiency is consistent al. 1994, Enríquez et al. 1994) to regulate light absorption properties of marine photosynthetic organisms, is, therefore, also an important descriptor of their photothetic metabolism.

Tissue thickness and pigment concentration not only differences in the continuous response of photosynthesis to irradiance, as described by the linearised Burke \& Lineweaver model (Lederman \& Tett 1981). The

$$
\begin{aligned}
\frac{1}{P_{\text {gross }}}= & 30.41( \pm 3.55) \times \frac{1}{I}+27.95( \pm 2.59) \text { thickness } \times \frac{1}{I} \\
& -113.03( \pm 10.86)(\text { thickness } \times \text { chl } a) \times \frac{1}{I}
\end{aligned}
$$

which accounts for $54 \%$ of the variation observed in the 268 photosynthetic light response curves examined $(F=78.49, \mathrm{p}<0.001)$. Tissue thickness and the product of tissue thickness and chl a concentration covaried with the slope of the model, which corresponds to the inverse of $\alpha$. No significant coefficients were found for the intercept of the model (the inverse of $P_{\max }$ ).

To test the broad-scale applicability of our results for marine macrophytes, we compiled a broader data set, adding to our own experimental values the physiological photosynthetic descriptions and their associated plant traits of 116 marine macrophyte species (103 macroalgae and 13 seagrasses), from the literature and hitherto unpublished work (Sand-Jensen unpubl.). We confirmed with the larger data set the patterns found for Mediterranean macrophytes. Thus we found the same linear relationship between $\alpha$ and $P_{\max }$ (Eq. 9 in Table 4) by considering 90 different macrophyte species without including the seasonal variability within species 
(as in the Mediterranean data set). Photosynthetic rates normalised to dry weight were again strongly correlated with tissue thickness $\left(\mathrm{r}_{\bar{P}_{\max }}=-0.62, \mathrm{r}_{\alpha}=\right.$ $-0.71, \mathrm{p}<0.001$; Eqs. 10 \& 11 in Table 4); and the multiple influence of thickness and chl a concentration could explain an important fraction of the variability displayed by photosynthetic rates normalized to dry weight (i e. $46 \%$ for $P_{\max }$ and $58 \%$ for $\alpha_{i}$ Eqs. $12 \& 13$ in Table 4).

The results presented confirm the existence of a strong, negative relationship between the photosynthetic rates at low $(\alpha)$ and saturating $\left(P_{\max }\right)$ light and the thickness of tissues of NW Mediterranean macrophytes and marine macrophytes in general. It is important to stress that the strong negative relationships of $P_{\max }$ and $\alpha$ to thallus thickness persist irrespective of whether photosynthetic rates are scaled to tissue dry weight or chl a concentration and despite differences in environmental conditions with site and time for the collected macrophytes. The scaling of macrophyte photosynthesis to tissue thickness is implicit in the 'Form-Function' hypothesis (Littler 1980), and has also been demonstrated previously for a set of Atlantic macrophytes (Lüning \& Dring 1985, Frost-Christensen \& Sand-Jensen 1992). The quantitative description of these relationships represents a step forward in the search for patterns in macrophyte photosynthesis because they should allow quantitative, if coarse, predictions. The empirical relationships described here are also consistent with theory, stating that specific light absorption, which is believed to be the main determinant of photosynthetic efficiency (Geider et al. 1986), depends on the interaction between chl a concentration and tissue thickness (Ramus 1978, Morel \& Bricaud 1981, Agustí et al. 1994). Light absorption may not, however, be the only mechanism involved in the close scaling of photosynthetic metabolism to tissue thickness, because increasing tissue thickness is also associated to reduced surface to volume ratios and, therefore, to reduced efficiency of gas and solute exchange across the macrophyte surfaces (Hein et al. 1995).

Adaptive responses to environmental changes of individual plant species or homogeneous taxonomical groups (e.g. marine angiosperms) will involve important plant traits other than tissue thickness which will influence the photosynthetic performance. This aspect is well illustrated by the considerable residual variation in the regression equations and in Figs. 1 to 3 . Leaf and tissue thickness usually change within narrow, genetically imposed, ranges for individual species and can only account for a small proportion of within-species variability in photosynthetic performance, as a response to environmental changes (e.g. light climate, nutrient availibility). Alternatively, our results illus- trate the general changes in photosynthetic properties associated with the variability of tissue thickness among species, and should, therefore, be interpreted in an evolutionary perspective.

The importance of tissue thickness to scale differences in the photosynthetic metabolism of marine macrophytes adds to previous demonstrations of a central adaptive role of tissue thickness and the associated surface to volume ratio. This central role parallels that already identified for land plants, for which tissue thickness has been shown to influence light capture, photosynthetic metabolism, growth and life span (Reich et al. 1991, Lambers \& Poorter 1992, Reich 1993). Accordingly, the photosynthetic metabolism, light utilization, nutrient absorption, and growth of both microalgae (Taguchi 1976, Chan 1978, Morel \& Bricaud 1981, Banse 1982, Geider et al. 1986, Sakshaug et al. 1989, Agustí 1991) and macroalgae (King \& Schramm 1976, Ramus 1978, 1990, Littler 1979, 1980, Littler \& Littler 1980, Ramus \& Rosenberg 1980, Lüning \& Dring 1985, Nielsen \& Sand-Jensen 1989, 1990, Frost-Christensen \& Sand-Jensen 1992, Enríquez et al. 1994) are closely associated to tissue thickness. These findings suggest the existence of a general relationship between tissue thickness and the performance of marine plants (Duarte 1994), which may help to predict and understand their abundance and dynamics in the oceans.

Acknowledgements. This research was supported by grants from the Ramón Areces Foundation, the Spanish Interministerial Commission of Science and Technology (CICYT, MAR91-0503), and the European Community [STD program, CI1 ${ }^{\circ}$-CT91-0952 [HSMU\}). We thank Nuria Marbá and Just Cebrian for assistance in the field, and Olga Delgado for assistance in laboratory work. We also thank the anonymous reviewers for helpful comments on the manuscript.

\section{LITERATURE CITED}

Agusti, S. (1991). Allometric scaling of light absorption and scattering by phytoplankton cells. Can. J. Fish. Aquat. Sci. 48: $763-767$

Agustí, S., Enriquez, S., Frost-Christensen, H., Sand-Jensen, K., Duarte, C. M. (1994). Light harvesting in the plant kingdom. Funct. Ecol. 8: 273-279

Ballesteros, E. (1991). Seasonality of growth and production of a deep-water population of Halimeda tuna (Chlorophyceae, Caulerpales) in the North-western Mediterranean. Botanica mar. 34: 291-301

Banse, K. (1982). Cell volumes, maximal growth rates of unicellular algae and ciliates, and the role of ciliates in the marine pelagial. Limnol. Oceanogr. 27: 1059-1071

Bijl, van der L., Sand-Jensen, K., Hjermind, A. L. (1989) Photosynthesis and canopy structure of a submerged plant, Potamogeton pectinatus, in a Danish lowland stream. J. Ecol. 77: 947-962

Chan, A. T (1978). Comparative physiological study of marine diatoms and dinoflagellates in relation to irradi- 
ance and cell size. 1. Growth under continuous light. J. Phycol. 14: 396-402

Chapin, F. S. Ill, Bloom, A. J., Field, C. B., Waring, R. H. (1987). Plant responses to multiple environmental factors BioSci. 37:49-87

Charpy-Roubaud, C., Sournia, A (1990). The comparative estimation of phytoplanktonic, microphytobenthic, and macrophytobenthic primary production in the ocean. Mar Microb. Food Webs 4: 31-57

Dawes, C., Chan, M., Chinn, R., Koch, E. W., Lazar, A. Tomasko, D. (1987) Proximate composition, photosynthetic and respiratory responses of the seagrass Halophila engelmanii from Florida. Aquat. Bot. 27: 195-201

Dennison, W. C. (1990). Chlorophyll content. In: Phillips, R. C., McRoy, P. (eds.) Seagrass research methods. UNESCO, Paris, p. 83-85

Dennison, W. L., Alberte, R. S. (1982) Photosynthetic responses of Zostera marina L. (eelgrass) to in situ manipulations of light intensity. Oecologia 55: 137-144

Draper, N. R., Smith, H. (1966). Applied regression analysis. Wiley \& Sons, Chichester

Drew, E. A. (1978) Factors affecting photosynthesis and its seasonal variation in the seagrasses Cymodoea nodosa (Ucria) Aschers, and Posidonia oceanica (L.) Delile in the mediterranean. J. exp. mar. Biol. Ecol. 31: 173-194

Duarte, C. M. (1992). Nutrient concentration of aquatic plants Limnol. Oceanogr 37: 882-889

Duarte, C. M. (1994). Submerged aquatic vegetation in relation to different nutrient regimes. Ophelia (in press)

Durako, M. J. (1993). Photosynthetic utilization of $\mathrm{CO}_{2}$ (aq) and $\mathrm{HCO}_{3}{ }^{-}$in Thalassia testudinum (Hydrocharitaceae). Mar. Biol. 115: 373-380.

Enríquez, S., Agusti, S., Duarte, C. M. (1994). Light absorption by marine macrophytes. Oecologia 98 : 121-129

Evans, J. R. (1989). Photosynthesis - the dependence on nitrogen partitioning. In: Lambers, H., Cambridge, M. L. Konings, H., Pons, T. L. (eds.) Causes and consequences of variation in growth rate and productivity of higher plants. SPB Academic Publishing, The Hague, p. 159-173

Field, C., Mooney, H. A. (1986). The photosynthesis-nitrogen relationship in wild plants. In: Givnish, T. J. (ed.), On the economy of plant form and function. Cambridge University Press, Cambridge, p. 25-55

Frost-Christensen, H., Sand-Jensen, K. (1992). The quantum efficiency of photosynthesis in macroalgae and submerged angiosperms. Oecologia 91: 377-384

Geider, R. J., Osborne B. A. (1992). Algal photosynthesis. The measurement of algal gas exchange. Chapman and Hall, New York

Geider, R. J., Platt, T., Raven, J. A. (1986). Size dependence of growth and photosynthesis in diatoms: a synthesis. Mar Ecol. Prog. Ser. 30: 93-104

Grime, J P. (1974). Vegetation classification by reference to strategies. Nature 250: 26-31

Harding, L. M. Jr, Fisher, T. R. Jr, Tyler, M. A. (1987). Adaptive responses of photosynthesis in phytoplankton: specificity to time-scale of change in light. Biol. Oceanogr. 4: $403-437$

Hein, M., Pedersen, M. F., Sand-Jensen, K. (1995). Sizedependent nitrogen uptake in micro- and macroalgae. Mar. Ecol. Prog. Ser. 118: 247-253

Josselyn, M., Fonseca, M. (1986). Biomass, production and decomposition of a deep water seagrass, Halophila decipiens Ostenf. Aquat. Bot. 25: 47-61

Kautsky, L. (1988). Life strategies of aquatic soft bottom macrophytes. Oikos 53: 126-135

Kemp, M., Murray, L., McRoy, C. P. (1990). Primary produc- tivity. In: Phillips, R. C., McRoy, P. (eds.) Seagrass research methods. UNESCO, Paris, p. 83-85

King, R. J., Schramm, W. (1976). Photosynthetic rates of benthic marine algae in relation to light intensity and seasonal variations. Mar. Biol. 37: 215-222

Kirk, J. T O. (1983). Light and photosynthesis in aquatic ecosystems. Cambridge University Press, Cambridge

Koroleff, F. (1983). Determination of phosphorus. In: Grasshoff, K., Egrardt, M., Kremling, K. (eds.) Methods of seawater analysis, 2nd edn. Verlag-Chemie, Nürnberg, $p$ $125-139$

Lambers, H., Poorter, H. (1992). Inherent variation in growth rate between higher plants: a search for physiological causes and ecological consequences. Adv. ecol. Res. 23 $187-261$

Lederman, T. C., Tett, P. (1981). Problems in modeling the photosynthesis-light relationship for phytoplankton. Botanica mar. 24: 125-134

Lipkin, Y., Beer, S., Best, E. P. H., Kairesalo, T., Salonen, K (1986). Primary production of macrophytes terminology, approaches and a comparison of methods. Aquat. Bot. 26: $129-142$

Littler, M. M. (1979). The effects of bottle volume, thallus weight, oxygen saturation levels, and water movement on apparent photosynthetic rates in marine algae. Aquat. Bot. $7: 21-34$

Littler, M. M. (1980). Morphological form and photosynthetic performances of marine macroalgae: test of a functional/form hypothesis. Bot. Mar. 23: 161-165

Littler, M. M., Arnold, K. E. (1982). Sources of variability in macroalgal primary productivity: sampling and interpretative problems. Aquat. Bot. 8: 141-156

Littler, M. M., Littler, D. S. (1980). The evolution of thallus form and survival strategies in benthic marine macroalgae: field and laboratory tests of a functional form model. Am. Nat. 116: 25-44

Lüning, K., Dring, M. J. (1985). Action spectra and spectral quantum yield of photosynthesis in marine macroalgae with thin and thick thalli. Mar. Biol. 87: 119-129

Madsen, T V., Sand-Jensen, K., Beer, S. (1993). Comparison of photosynthetic performance and carboxylation capacity in a range of aquatic macrophytes of different growth forms. Aquat. Bot. 44: 373-384

Morel, A., Bricaud, A. (1981). Theoretical results concerning light absorption in a discrete medium, and application to specific absorption of phytoplankton. Deep Sea Res. 28 1375-1393

Nielsen, S., Sand-Jensen, K. (1989). Regulation of photosynthetic rates of submerged rooted macrophytes. Oecologia 81: $364-368$

Nielsen, S., Sand-Jensen, K. (1990). Allometric scaling of maximal photosynthetic growth rate to surface/volume ratio. Limnol. Oceanogr. 35: 177-181

Ramus, J. (1978). Seaweed anatomy and photosynthetic performance: the ecological significance of light guides, heterogeneous absorption and multiple scatter. J. Phycol. 14: $352-362$

Ramus, J. (1983) A physiological test of the theory of complementary chromatic adaptation. II. Brown, green, and red seaweeds. J. Phycol. 19: 173-178

Ramus, J. (1990). A form-function analysis of photon capture for seaweeds. Hydrobiologia 204/205: 65-71

Ramus, J., Rosenberg, G. (1980). Diurnal photosynthetic performance of seaweeds measured under natural conditions. Mar. Biol. 56: 21-28

Ramus, J., Venable, M. (1987) Temporal ammonium patchiness and growth rate in Codium and Ulva (Ulvophyceae). 


\section{J. Phycol. 23: 518-523}

Raunkiaer, C. (1934). The life forms of plants and statistical plant geography. Clavendon Press, Oxford

Reich, P. B. (1993). Reconciling apparent discrepancies among studies relating life span, structure and function of leaves in contrasting plant life forms and climates: 'the blind men and the elephant retold'. Funct. Ecol. 7: 721-725

Reich, P. B., Uhl, C., Walters, M. B., Ellsworth, D. S. (1991). Leaf life span as a determinant of leaf structure and function among 23 tree species in Amazonian forest communities. Oecologia 86: 16-24

Sakshaug, E., Andersen, K., Kiefer, D. A. (1989). A steady state description of growth and light absorption in the marine planktonic diatom Skeletonema costatum. Limnol. Oceanogr. 34: 198-204

Sand-Jensen, K. (1988). Photosynthetic responses of Ulva lactuca at very low light. Mar. Ecol. Prog. Ser. 50: 195-201

Sand-Jensen, K., Madsen, T. V. (1991). Minimum light re-

This article was presented by G. W. Thayer (Senior Editorial Advisor), Beaufort, N. Carolina, USA quirements of submerged freshwater macrophytes in laboratory growth experiments. J. Ecol. 79: 749-764

Smith, S. V (1981). Marine macrophytes as a global carbon sink. Nature 211: $838-840$

Sokal, R. R., Rohlf, F. J. (1979). Biometría. Principios y métodos estadísticos en la investigación biológica. H. Blume Ediciones, Madrid

Staehelin, L. A. (1986). Chloroplast structure and supramolecular organization of photosynthetic membranes. In: Staehelin, L. A., Arntzen, C. J. (eds.) Photosynthesis III: Photosynthetic membranes and light harvesting systems. Encyclopedia of plant physiology. New series, Vol. 19. Springer-Verlag, Berlin, p. 1-84

Taguchi, S. (1976). Relationship between photosynthesis and cell size of marine diatoms. J. Phycol. 12: 185-189

Tomasko, D. A., Dawes C. J. (1989), Effects of partial defoliation on remaining intact leaves in the seagrass Thalassia testudinum Banks ex Konig. Botanica mar. 32: 235-240

Manuscript first received: April 5, 1994

Revised version accepted: November 29, 1994 